\title{
The Development of Bilbo Baggins' Character through Leadership in J.R.R. Tolkien's The Hobbit
}

\author{
Iline Megale \& F.X. Dono Sunardi \\ Dono.sunardi@machung.ac.id \\ Faculty of Language and Arts, Universitas Ma Chung Malang
}

\begin{abstract}
Leadership has been interesting since it refers to a significant quality applicable to a wide context of human's life. Traditionally, there are two points of views related to leadership. One sees it is a trait one was being born with, and the other as a cultivated trait. Galton (1869) suggests how extraordinary intelligence as an important key of leadership is something inherited. However, this view has been challenged by newer theories, being one of them is servant-leadership introduced by Greenleaf in 1977. This model believes that in order to become a leader, one must firstly learn how to be a servant. The Hobbit (1937) by J.R.R. Tolkiens is a great showcase as to how servant-leadership is cultivated along the personal development of its main character, Bilbo Baggins. The novel narrates how Bilbo joins an expedition of dwarves as a servant and through these he learns how to become a leader. Since the focus is the character development of Bilbo and the servant-leadership attributes he cultivates along the way, this research employs qualitative method. The finding confirms the presumption that Bilbo Baggins is a round and dynamic character because of its complexities and developments throughout the story. Toward the end of the story, Bilbo succeeds in developing nine leadership attributes, i.e. vision, honesty, integrity, trust, service, modeling, pioneering, appreciation of others, and empowering. These attributes are not something Bilbo naturally endowed with, but he develops, practices, and cultivates them. It is also found that the attribute of service, as the heart of servant-leadership, is dominant in Bilbo Baggins. The findings also suggest that leadership as a trait is something that can be learned from an exploration into a literary work.
\end{abstract}

Key words: leadership, servant-leadership, character development

\section{Introduction}

Leadership, just like many other human traits, cannot be neatly separated from the actor behind it. In this case, it is a leader. A leader should develop certain qualities that make him or her capable of facing any kind of situations and leading others in sustainable ways to overcome the hard times. It is along the line of this argument that not everyone can be a leader (since not everyone is able to face difficult times, let alone help others on the times of hardship), Francis Galton, with his Trait Theory (as cited in Zaccaro, Kemp and Bader 2004, p. 102), explains how extraordinary intelligence is one of the keys to leader attribute and thus argues that leadership is inherited, not developed kind of attribute.

In contrast, leadership theories from the later period challenged this. McGeeCooper and Trammell (2013), for example, 
states that servant leadership, a model developed by Greenleaf in 1977, can move traditional notions of leadership and prepare companies (or any groups) to face the challenges of an uncertain future. Servant leadership model believes that to be a leader, one should be a servant first. Leadership is not a static human attribute but a skill that can be trained through learning and life experience.

Training of leadership can happen in many different way, being one of them which is indirect and yet effective is through reading and exploring into literary works. According to Barnet, Burto and Cain (2008), compared to writers of different genres such as journalists, authors of do-it-yourself manuals, and authors of textbooks, writers of literature are special because what they do is recording their responses to life and imagining the responses of others. It is the reason why reading and exploring into literary works can be a great way to learn about human being and its matter, including on the topic of leadership. And novel, as the new form of literary works, is a longer form of fiction which is relatively realistic in portraying and representing human lives (Barnet, Burto and Cain 2008). Albeit its indirectness in giving life instructions, fiction, as suggested by Badaracco (2006) in regards with leadership and organizational behavior, can be as instructive as any business textbook.

Along this line, The Hobbit (1937) by J. R. R. Tolkien, can be a great showcase to explore human lives' representation. Readers can learn about, among others, the topic of leadership through the exploration of its characters development. Despite the fact that Tolkien (as cited in Carpenter 1981) meant it as a children's story, The Hobbit is undoubtedly a representation of leadership in real life. As suggested by its title, The Hobbit is the story of its main character of it, i.e. a hobbit which can be described as a member of an imaginary race similar to humans, of small size and with hairy feet. In particular, it narrates the adventure of a particular hobbit, named Bilbo Baggins. Bilbo tries to help, in literal way as the servant, the
King of dwarves to conquer Smaug, the dragon, so that the King can reclaim the throne of Lonely Mountain. In the beginning of the story, therefore, Bilbo does not assume any leadership position. He is by himself among the group of dwarves he serves. As the story goes, however, he develops certain leadership qualities.

The paper tries and aims at achieving two objectives, namely (1) to describe how the character of Bilbo Baggins develops in The Hobbit, which will require some exploration into the intrinsic elements of the novel, and (2) to identify servant leadership attributes that appear in Bilbo Baggins as his character develops.

\section{Novel and Characters}

Novel is one more current, longer narrative form of literary works. As a narrative, novel involves events (which make up the story line and plot), characters, and what the characters say and do (Abram 1999). As one form of literary works, novel is of course a work of fiction. So saying, a character in a novel differs from a historical figure or a figure in real life. He or she is created only of sentences describing him or her or being put into his mouth by the author (Wellek and Warren 1949: 15). However, Hallet (n.d.) highlights how fiction writers aim at creating "legitimate untruths," which refers to their insistence in seeking to demonstrate meaningful insights into the human condition. Therefore, fiction is "untrue" in the absolute sense, but true in the universal sense. Moreover, Plato (as cited in Wellek and Warren 1949) calls fiction as an artistic verbal imitation of life. The opposite of fiction is not "truth" but "fact" or "time and space existence". The great service of a novel reveals the introspective life of the characters (Forster 1927). Good novels, therefore, are source books for psychologists to see and explore various characters. In addition, the act of reading novel and relating ourselves to its characters is also a way for us to express emotion and relieve us from great pressure of real life. 
It is in this view that we should read The Hobbit, a fantasy novel, a genre of fiction, and understand its (main) characters. The Hobbit is perceived as a high fantasy novel whose setting is in a created world or imaginary kingdom. The tone of the story is serious; it focuses on the conflict between opposing forces and concerns with big questions as well as ultimate values such as goodness, truth, courage, or wisdom (Albernarle County Public Schools 1996).

Tolkien (as cited in Foster 1981) is known to elaborate his own view upon fantasy world. A fantasy world is perceived as a serious Secondary World (or "subcreation"), which is an escape from Primary World. Therefore, a fantasy world is a mirror, a re-presentation of the real world. There are four terms employed to describe this situation, i.e. recovery, escape, consolation, and eucatastrophe. Recovery means that Secondary World can give readers a sense of wonder and appreciation because they can gain a clear view about a world with different situation and creatures. It is a way to escape from the common problems in the real world and open an opportunity to "converse" with other living creatures. But still, the fulfillment of these escapes is one of the consolations of the happy ending. In the best form, the happy ending is a eucatastrophe, an unexpected turning of the plot.

Some characters in J. R. R. Tolkien's The Hobbit (1937) exhibit strong leadership attributes. Urick (2014), for instance, in his research found that the characters of Gandalf, Aragorn, and Bilbo are effective leaders because they possess qualities described in transformational and servant leadership theories. Urick's work is, therefore, one of several papers that proves The Hobbit is a good source to learn about leadership.

Character is one of several intrinsic elements of a novel, being the others are plot, point of view, setting and theme. Exploring into character is one of the most frequent and significant ways taken by a student of literature to understand a novel. It might be due to the relatively easiness to relate the lives of a novel's characters with one's own life.

Theoretically speaking, there are some common ways to categorize characters in a novel. The most popular categorization is probably by Forster (1927) who divided characters into round and flat. Flat characters are a single character line and act as a function of only a few fixed character traits. Round characters, meanwhile, are complex figures who have dimensional personalities. The second categorization of character dividing it into static and dynamic. Kokemuller (2016) writes a static character is one who does not undergo any significant change in character, personality or perspective along the story. Thus, as stated by Holman (1980), a static character only can be seen from the pattern of the action and not the changing of character toward something. A dynamic character, in contrast, is the one who might experience a major life transition, a coming-of-age experience, trials, and tribulations, a change of heart or develop more likeable qualities or take a turn for the worse. He is changed by his actions and those actions impact upon the character.

It can be argued that the reason for our relative easiness as readers to relate with character(s) of a novel is facilitated by characterization. Characterization itself is a general term for sentences or the concepts which are employed to characterize in the sense explained or for the act of speaking so (Aschenbrenner 1983). Certainly, a method is needed in characterization. Minderop (2005) suggests that the common direct and indirect methods are not the only one characterization method. Other methods can be utilized as well such as point of view, stream of consciousness, figurative language, and also character's motivation in doing something. However, direct and indirect method becomes the focus in this paper.

Moreover, Holman (1980) explains there are three fundamental methods of characterization in fictions. First is the explicit presentation by the author of the character through direct narration either in an introductory part or more often 
throughout the work, illustrated by the action. It can be said as direct method. Second, the author presents the characters by their actions and less or without giving his explicit comments on them. Third is the representation from within a character inner self and without the author's comment. The last two methods are called as indirect method.

Minderop (2005) explains further that telling (direct) method consists of characterization through characters' names, looks, and narrator's speech. Showing (indirect) method consists of dialog and action. Characterization through dialog includes what the narrator says, the personality of the narrator, dialog location, and situation, the personality of the characters which are referred by narrator, mental quality of the characters, tone, stress, dialect, and vocabulary of characters. Meanwhile, characterization through characters' action includes face expression and motivation of the characters. This paper will only employ direct characterization through names, looks, and narration as well as indirect characterization through character's action, other's opinion, and dialog.

\section{Servant Leadership}

Greenleaf (as cited in McGee-Cooper and Trammell, 2013) provides us with a definition of a servant-leader. A servantleader is a person who begins with the natural feeling of willingness to serve first. As such, he or she develops some characteristics, like willingness and readiness to help, support, encourage, and lift up others. And because of their noble role model, others begin to be inspired and moved.

Russell and Stone (2002: 146-152) formulate nine functional attributes of servant leadership. The classification of functional attributes is a result of their repetitive appearance in many literatures. The first attribute is vision. Vision is a clear idea of what leader wants to do. It becomes his strength to persist in facing declines and failures (Bennis, 2009: 33).
The next attributes are honesty and integrity. A leader with integrity honors his or her commitments and promises (Bennis, 2009: 152). There are three essential parts of integrity: self-knowledge, candor and maturity (Bennis, 2009: 34-35). Selfknowledge is about knowing personal strength and weakness which is important. Candor is based on honesty to personal action and thought. Maturity talks about how well a leader grows as a person through learning to be dedicated, observant, capable of working with, and learning from others.

The fourth attribute is trust. Integrity is the basis of trust. Trust is one that must be earned which is given by the co-workers and followers (Bennis, 2009: 35). The fifth is service. Service is the core of the servant leadership. The fundamental motivation should come from the heart that is willing and ready to serve. A leader who makes visible self-sacrifices in the service of the organization will be viewed as more sincere and committed (Yukl 2010). The next or sixth attribute is modeling. Malphurs (as cited in Russel and Stone 2002) says effective leaders introduce values through deeds (or models) as much as or more than through words.

Another attribute is pioneering. Ulrich (as cited in Russel and Stone 2002) states leaders need to be pioneers who take risks, create new paths, shape new approaches to old problems and have strong values and beliefs that drive their actions. The next attribute is appreciation of others. Spears (2010) breaks down into some point of characteristics which are listening, empathy, and healing. Listening with periods of reflection is essential to the growth of servant leadership. By listening, a servant-leader does not only try to understand others but also empathize with them. A servant-leader will accept and recognize his members' uniqueness. This kind of leadership will transform inside the team. The relationship among members will be healed.

The last or ninth attribute is empowerment. Empowerment perceives that the leader values workers as the best parts of the corporate machine (Fairholm and 
Fairholm, 2009: 79). Giving others the power required to perform a given act means granting another the practical autonomy to step out and contribute directly to his or her job. But, it does not mean that leaders give away their power.

\section{The Character Development of Bilbo Baggins}

In order to show the character development (and changes) that Bilbo Baggins experiences in the course of the story, we will take a closer look of it and make a comparison between Bilbo before his adventure as a helper to the dwarves and after.

\section{Bilbo Baggins before Taking the Adventure}

There are several strong inferences from the novel about how Bilbo Baggins as a hobbit used to live before embarking on the adventure with the dwarves. The first and foremost characteristic of living as a hobbit is the love to living in comfort zone. This refers to a state that is in contrast with leaving safety and taking a risk of adventuring the unknown. As can be read in The Hobbit:

"I should think so - in these parts! We are plain quiet folk and have no use for adventures. Nasty .disturbing uncomfortable things! Make you late for dinner! I can't think what anybody sees in them," said our Mr. Baggins,...(p. 9)

Bilbo, as a typical hobbit, will not usually take a dangerous path of adventure. He prefers to stay at home, prepare regular meal, and live a life like "normal" hobbits of his village. Bilbo cannot even make it why there are those who like to take adventure and put themselves in danger.

Just like his fellow hobbits, Bilbo is also a warm and polite personality. One day, when he meets Gandalf, a wizard who has known Bilbo's mother for so long, Bilbo cannot but show his warmth and politeness to him. As can be read:
"Good morning!" he [Bilbo] said at last. ...

"What a lot of things you do use Good morning for!" said Gandalf. "Now you mean that you want to get rid of me, and that it won't be good till I move off."

"Not at all, not at all, my dear sir! Let me see, I don't think I know your name?" (p. 9)

Politeness and warmth to strangers can take form in many small talks. Despite the fact that Bilbo wants to express his rejection to Gandalf's offer to have an adventure, he keeps saying "good morning" and "thank you" to the later. It suggests how Bilbo does not want to hurt a stranger who he has just met.

The coming of the thirteen dwarves to his house also surprises Bilbo in not a very good way. They come to him much like intruders to his peaceful life. As narrated, he liked visitors, but he would like to know them before they arrived (p. 11). However, when they do come, Bilbo cannot but show his characteristic, almost automated, warmth and politeness.

"Come along in, and have some tea!" he managed to say after taking a deep breath.

"A little beer would suit me better, if it is all the same to you, my good sir," said Balin with the white beard. But I don't mind some cakeseed-cake, if you have any."

"Lots! Bilbo found himself answering, to his own surprise; and he found himself scuttling off, too, to the cellar to fill a pint beer-mug, and to the pantry to fetch two beautiful round seed-cakes which he had baked that afternoon for his aftersupper morsel. (p. 11)

Repressing his own true feeling, Bilbo welcomes everybody who comes to his house. He prepares everything the dwarves, his guests who at the same time the intruders, need, including their preference for food and drink. But this comes as something he himself cannot avoid. He has been trained to be polite and warm to all. This also suggests that Bilbo is not an assertive person. 
Bilbo's warmth and politeness, however, also opens up new opportunities for him. As Bilbo follows the conversation taking place in his house, he hears the beautiful, enchanting songs of the dwarves. Bilbo himself is someone who loves aesthetic works, including songs. And, those songs sung by his dwarf guests inspire him to explore the wonderful world outside his current place. "[S]omething Tookish woke up inside him, and see the great mountains..." (p. 16)

As Bilbo's interests in the topic of world exploration mount up, and the side of himself that longs for adventure swells, there comes a moment when the dwarves express their disbeliefs in Bilbo's ability to help them in their dangerous journey. One of them, Gloin, says, " Humph!" ... As soon as I clapped eyes on the little fellow bobbing and puffing on the mat, I had my doubts. He looks more like a grocer-than a burglar!" (p. 18). However, Gandalf, the wizard, determines that Bilbo Baggins is a burglar that he has chosen and who will prove to be useful for them later.

Thorin, the leader of the dwarves, finally concedes and decides to take Bilbo in the journey. In the conversation taking place at the night before the departure, he makes this point clear, although he will not assign an important role to him. As we can read:

"I think we have talked long enough for one night, if you see what I mean. What about bed, and an early start, and all that? I will give you a good breakfast before you go."

"Before we go, I suppose you mean," said Thorin. "Aren't you the burglar? And isn't sitting on the doorstep your job, not to speak of getting inside the door? (p. 23)

Despite the dwarves' doubtfulness on his future usefulness, Bilbo decides to go with Thorin and the companions. But this is not happening before: (1) he gets "a letter of invitation" from the dwarves to join their adventure, which the dwarves agree to write, and (2) a last-minute push from Gandalf, an external force outside Bilbo that makes him embarking on the journey:

"That leaves you just ten minutes. You will have to run," said Gandalf.

"But-" said Bilbo.

"No time for it," said the wizard.

"But-"said Bilbo again.

"No time for that either! Off you go!"

Bilbo is, therefore, a hobbit that needs an external push to take a risk. Indeed, he felt some interest in exploring the world outside his safe house and is formally invited to join an adventure, but he still need someone to kick start him.

\section{Bilbo Baggins after Taking the Adventure}

There are many changes in the character of Bilbo Baggins after he decides to join the journey of the dwarves. These changes, which positively seen as developments, are evidently results of experiences that he has during the trip, many of which, as can be expected from a fantasy novel like The Hobbit, are dramatic. Here are some changes in Bilbo as he proceeds on his journey as a burglar for the dwarves.

\section{a. Being a braver hobbit}

If prior to his journey, Bilbo is a meek hobbit, because of the experiences he faces during his journey, Bilbo becomes a braver and, to some extent, a risk taker character. One night, for example, he is asked by Thorin to check where a certain bright light comes from (it is not too far from their place to rest for the night). Bilbo cannot but accept and do the order as his position is the burglar. So, despite his own being terrified, he embraces himself to see what happens.

Upon his investigation, Bilbo finds the bright light comes from three trolls. Trolls are monster-like creatures that eat man-flesh. The trolls that Bilbo sees are in the middle of their discussion about the dish. Bilbo has never met that kind of creature before but ever read about them. Surely Bilbo feels terrified at what he finds but he persists on doing what he can do and finds out more in 
order to bring something back to Thorin and his companies. He acts more bravely than he would have been if he keeps staying in his village.

Bilbo knew it. He had read of a good many things he had never seen or done. He was very much alarmed, as well as disgusted; he wished himself a hundred miles away, and yet- and yet somehow he could not go straight back to Thorin and Company empty-handed (p. 30).

\section{b. Becoming a smarter one}

At one point of the novel, Bilbo, after accidently being left behind by the group, meets another strange creature. It is a Gollum. Bilbo then exchanges riddles with it and there he shows up how smart he is in answering and making riddles that he comes up as the winner. The last question he raises cannot be answered by the Gollum as he does not originally intend it as the riddle: "What have I got in my pocket?" he said aloud. He was talking to himself, but Gollum thought it was a riddle, and he was frightfully upset" (pp. 58-59).

Although that question is unintentional, this shows how Bilbo is very keen and smart in using the opportunity. Eventually, he is able to escape with the help of the magic ring he gets in the cave of Gollum, which enables him to be reunited with his group.

\section{c. Being a reliable helper}

As the story unfolds, Bilbo's "patron" and the one who has chosen him as a burglar, Gandalf, departs from the expedition. This, of course, comes as a not very nice surprise for Bilbo. He is going to be on his own from the moment Gandalf leaves. He feels doubtful about himself, as can be read:

"Do we really have to go through?" groaned the hobbit.

"Yes, you do!" said the wizard, "if you want to get to the other side. You must either go through or give up your quest. And I am not going to allow you to back out now, Mr. Baggins. I am ashamed of you for thinking of it. You have got to look after all these dwarves for me," he laughed. (p. 98)

The responsibility that Gandalf entrusts on him to take care of the dwarves is not something light. And yet, in the ends Bilbo determines to give his best service to the cause.

The departure of Gandalf makes it possible for Bilbo to grow into a reliable helper for the group. Without Bilbo's defeating the spiders, for instance, the dwarves could not be saved: "They knew only too well that they would soon all have been dead, if it had not been for the hobbit; and they thanked him many times" (p. 116).

\section{d. Being a firm and active "leader"}

There is a moment in the novel when the dwarves are being captivated by the elves of Mirkwood. Bilbo makes a plan to get them out of the jail. One option is to make use his magic ring, as he has done several times before this. But, his magic ring could not make all the members disappear at the same time. So cunningly Bilbo chooses to make the guards drunk and then instructs the dwarves to escape through the tunnel with barrels. His idea is protested by the dwarves but Bilbo shows his firmness as a leader as can be read:
"We shall be bruised and battered to pieces, and drowned too, for certain!" they muttered. "We thought you had got some sensible notion, when you managed to get hold of the keys. This is a mad idea!"'”
"Very well!" said Bilbo very downcast, and also rather annoyed. "Come along back to your nice cells, and I will lockyou all in again, and you can sit there comfortably and think of a better plan- but I don't suppose I shall ever get hold of the keys again, even if I feel inclined to try." (p. 124)

Bilbo's character is also getting stronger from day to day. He becomes a more self-confident hobbit than he used to be. He starts to think 
and act that the journey to Misty Mountains is his own business as well. It is not limited to only about helping the dwarves. It is also about himself. "Now strange to say Mr. Baggins had more than the others. He would often borrow Thorin's map and gaze at it" (pp. 140-141).

\section{e. Becoming someone who is willing to self-sacrifice}

Willingness to self-sacrifice is a sure sign of a true leader. And there are moments in the novel where Bilbo decides to sacrifice himself. By doing so, he earns trust and confidence from his dwarf companions, especially from Thorin, the leader. In one occasion, for example, it can be read:

"What then do you propose we should do, Mr. Baggins?" asked Thorin politely. ...

"Now I will make you an offer. I have got my ring and will creep down this very noon-then if ever Smaug ought to be napping-and see what he is up to. Perhaps something will turn up. 'Every worm has his weak spot,' as my father used to say, though I am sure it was not from personal experience." (p. 150)

By doing so, it does not mean that Bilbo does not feel afraid himself. He is horrified by this. However, he once again is able to manage unpredictable situations inside the cave. When his presence is smelt by the dragon, he can make Smaug not see him. In the end, he comes back safely from the cave.

\section{f. Being a loyal burglar}

As the story goes, we can see a more independent and confident Bilbo. His position among the dwarves gets ever stronger. One of his highest "achievements" as the burglar is his success in getting Arkenstone of Tharin, which is to Thorin the most valuable thing in the world. But that does not spare him from taking an opposite opinion from Thorin and his company when he deems necessary.
Bilbo's independence puts him at a risk of being hatred by Thorin. This surely is something he does not like. However, as a burglar, Bilbo is indeed very loyal to the dwarves. It is proved by his response when he is persuaded by the Elvenking not to go back to Thorin and stay with them instead.

"... I advise you to remain with us, and here you shall be honoured and thrice welcome."

"Thank you very much I am sure," said Bilbo with a bow. But I don't think I ought to leave my friends like this, after all we have gone through together." ( $\mathrm{p}$. 184)

\section{g. Being humble, kind, and influential}

After the Battle of Five Armies (a battle which is not anticipated before between Goblins and the wild Wolves in one side and Elves, Men, and Dwarves on the other side), Bilbo is reunited with the dwarves. Unfortunately, at this moment Thorin is dying and his last words express his regret towards Bilbo.

"Farewell, good thief," he said. "I go now to the halls of waiting to sit beside my fathers, until the world is renewed. I wish to part in friendship from you, and I would take back my words and deeds at the Gate."

Bilbo knelt on one knee filled with sorrow "Farewell, King under the Mountain!" he said. "This is a bitter adventure. Yet I am glad that I have shared in your perils that has been more than any Baggins deserves."

"No!" said Thorin. "There is more in you of good than you know, child of the kindly West. Some courage and some wisdom, blended in measure. If more of us valued food and cheer and song above hoarded gold, it would be a merrier world." (p. 195)

In the conversation above, Bilbo looks humble and kind. He has given a big influence in Thorin's life and the latter is grateful for it. Bilbo's sincerity can also be seen when he gives his little share to the Elvenking. 
"In what way have I earned such a gift, 0 hobbit?" said the king.

"Well, er, I thought, don't you know," said Bilbo rather confused, "that, er some little return should be made for your, er, hospitality. I mean even a burglar has his feelings. I have drunk much of your wine and eaten much of your bread."

"I will take your gift, O Bilbo the Magnificent!" said the king gravely. (p.198)

Bilbo is able to touch many hearts with his good attitude. He also gives a lot instead of asking or demanding what he wants (even though he grumbles a lot too). At the end of his adventure, Bilbo is praised by Gandalf.

Gandalf looked at him. "My dear Bilbo!" he said. Something is the matter with you! You are not the hobbit that you were." (p. 203)

Bilbo does not only succeed in completing the mission as a burglar but also develops his leadership characteristics that once was a dormant potential in need of exploration.

\section{The Servant Leadership Attributes of Bilbo Baggins}

From the discussion on Bilbo Baggins' character development, it can be said that he has nine functional attributes of servantleadership. They are vision, honesty, integrity, trust, service, modeling, pioneering, appreciation of others, and empowerment. Presumably, those attributes do not come all at once. Some of the attributes can be seen from the beginning of the story but the others emerge later on. But basically, Bilbo develops all of the attributes through the journey that he takes with the dwarves.

When Bilbo is assigned to be a burglar, he wonders what he should do. However, during the journey, he learns to be a good burglar. Furthermore, he makes his own decision to trade with the Elvenking and Bard. At this point he becomes a burglar who is capable of using his potentials very well. He becomes a visionary person who knows what he is doing and what he wants to do. He wants everyone feel satisfied though he knows his friendship with Thorin is at risk.

Bilbo shows honesty and integrity almost all the times. After being offered to join the adventure, he simply admits that he has no business to take a dangerous journey because he is a common folk. But when he finally decides to take that chance, he starts to do his best as a burglar.

It is true that Bilbo is not a leader of a group at the beginning of his journey. However, day by day, he gains more trust from the dwarves. Getting trust from the followers is important for a leader. Without it, the followers will never obey to the leader. In facts, Bilbo leads the dwarves when they are attacked by spiders and trapped in the Elves' jails. Bilbo is also a good model and pioneer. Instead of debating with the dwarves about who is going to volunteer to enter the cave of the dragon, he agrees to be the first who checks in. Actually, it is not his business but the dwarves', the ones who own the mountain. However, Bilbo speaks through his deeds by simply taking the first step.

The last attributes of servant-leader that belongs to Bilbo are appreciation of others and empowerment. They are important qualities in servant-leadership. Hall (as cited in Page and Wong, 2000) states that a servant-leader is the one who invests himself in enabling others, in helping them be and do their best. To be a leader is about appreciating others and helping them to be better. Bilbo does not show these attributes heavily in The Hobbit (maybe later in The Lord of the Rings) because here he is more empowered by Gandalf than empowering others. However, Bilbo starts to empower when he orders the dwarves to unite against the spiders. He also shows this quality when he encourages the dwarves to dare to take risk in order to escape from the Mirkwood's jail. In those examples, Bilbo does not only give order but he also does his part and supports the dwarves to solve the problem. It makes Bilbo is a truly servant-leader. 


\section{Conclusion}

J. R. R. Tolkien's The Hobbit (1937) has showcased several leadership characters. One of the leaders we have discussed here is Bilbo Baggins. In this paper, we explored character and characterization theories in order to know the character development of Bilbo Baggins. From there, we tried to analyze the servant leadership attributes found in Bilbo Baggins as his character develops.

It is found that the character of Bilbo Baggins develops and experiences changes during his journey with the dwarves. Before taking the adventure, Bilbo is described as a normal hobbit who loves food and comfort. It is said about him: "He had only just had breakfast, but he thought a cake or two and a drink of something would do him good after his fright" (p. 10). He is hard to gain trust from the dwarves because of his appearance and natures. But after taking the adventure and meeting with lots of unpredictable things and real challenges, like Trolls, Gollum, Big Spiders, Smaug, and the Dragon, Bilbo becomes a solid servant-leader. Therefore, Bilbo is perceived as a round character because of his character complexities and as a dynamic character because of his character development.

By exploring into the development of his characters, Bilbo is proved to have some servant-leader attributes as mentioned in Russell and Stone (2002: 146-152). They are vision, honesty, integrity, trust, service, modeling, pioneering, appreciation of others, and empowerment.

\section{References}

Abrams, MH. A Glossary of Literary Terms, 7th ed. New York: Heinle \& Heinle. 1999.

Albemarle County Public Schools. "Genre Definitions," n.d. Web. 14 April 2016. <https://www2.k12albemarle.org/dept /instruction/languagearts/curriculum \%20appendices/appendixf_genredef.pd $\mathrm{f}>$.

Aschenbrenner, K. Analysis of Appraised Characterization. Dordrecht, NL: D. Reidel Publishing Company. 1983.

Badaracco, JL 'Leadership in literature'. Harvard Business Review. 2006. Web. 24 March 2016, < http://www.asecsldi.org/dotAsset/292762.pdf.>.

Barnet, S, et al. An Introduction to Literature: Fiction, Poetry and Drama, 15th ed. London: Pearson Longman. 2008.

Bennis, W. On Becoming a Leader. Basic Books, New York. 2003.

Carpenter, H. The letters of J.R.R. Tolkien. London: George Allen \& Unwin. 1981.

Fairholm, MR \& Fairholm, GW. Understanding Leadership Perspectives: Theoretical and Practical Applications. New York: Springer. 2009.

Forster, E.M. Aspects of the Novel. New York: RosettaBooks LLC. 1927.

Foster, R. "Teacher's Guide: The Hobbit." Rev. A Jurskis, 1981. Web. 24 January 2016.

<http://www.randomhouse.com/catalo g/teachers_guides/9780345534835.pdf $>$.

Hallett, FNU. "Elements of Fiction," n.d. Web. 30 March 2016. <https://www.carrollwooddayschool.or g/uploaded/documents/ElementsofFict ion6-4-10.pdf $>$. 
Holman, C.H. A Handbook to Literature, 4th ed., Indianapolis, IN: The Bobbs-Merrill Company, Inc. 1980.

Kokemuller, N. "Dynamic vs Static Character Definitions and Examples". 2016. Web. 30 March 2016, <http://education.seattlepi.com/dynam ic-vs-static-character-definitionsexamples-4939.html>.

McGee-Cooper, A \& Trammell, D. "The Essentials of Servant Leadership: Principles in Practice". Rev. M Kosec, Ann McGee-Cooper \& Associates, Inc. 2016. Web. 12 April 2016, <http://amca.com/amca/wpcontent/uploads/The-Essentials-ofServant-Leadership-Final.pdf>.

\section{Minderop, A. Metode Karakterisasi Telaah} Fiksi. Jakarta: Yayasan Obor Indonesia. 2005.

Page, D. \& Wong, P.T.P. "A Conceptual Framework for Measuring ServantLeadership". 2000. Web. 12 April 2016, <https://www.twu.ca/academics/gradu ate/leadership/servant-

leadership/conceptual-framework.pdf>.

Rateliff, J.D. The History of the Hobbit. London, UK: HarperCollins. 2000.

Ross, A. "English Language and Literature for AQAB." 2002. Web. 13 May 2016, <https://books.google.co.id/books?isbn $=0435109855>$.

Russell, R.F. \& Stone, A.G. "A Review of Servant Leadership Attributes: Developing a Practical Model', Leadership \& Organization Development Journal, vol. 23, no. 3, pp. 145-157, 2002. Web. 12 April 2016, <http://strandtheory.org/images/Russ ell_Stone_-_SL_Attributes.pdf>.

Spears, L.C. "Character and Servant Leadership: Ten Characteristics of Effective, Caring Leaders". The Journal of Virtues \& Leadership, vol. 1, no. 1, pp. 25-30, 2010. Web. 10 April 2016,
$<$ http://www.spearscenter.org/HSLEss ay.pdf $>$.

Tolkien, J.R.R. The Hobbit. 1937. Web. 18 June 2015, <https://docs.google.com/file/d/0B_yp ZX3300UZWmJqYmE0ajg2Mjg/view>.

Urick, M.J. "Wizards, Hobbits, and Kings: Leadership in Tolkien's Middle-earth and Lessons for Business Leaders', pp. 21-29, Institute of Leadership in Management Inc., 2014. Web. 25 March 2016, <https://www.researchgate.net/profile /Michael_Urick/publication/27610165 6_Wizards_Hobbits_and_Kings_Leadersh ip_in_Tolkien's_Middleearth_and_Lessons_for_Business_Leader s/links/5550d21808ae93634ec9f059.p $\mathrm{df}>$.

Wellek, R. \& Warren A. 1949, Theory of Literature. New York. Harcourt, Brace and Company. 1949. Print.

Yukl, G. Leadership in Organizations, 7th ed. Upper Saddle River, NJ: Pearson Education, Inc. 2010. Print. and Bader, FNU. "Leader traits and attributes", The Major Schools of Leadership, pp. 101124, 2004. Web. <http://www.corwin.com/upmdata/5014_Antonakis_Chapter_5.pdf>. 